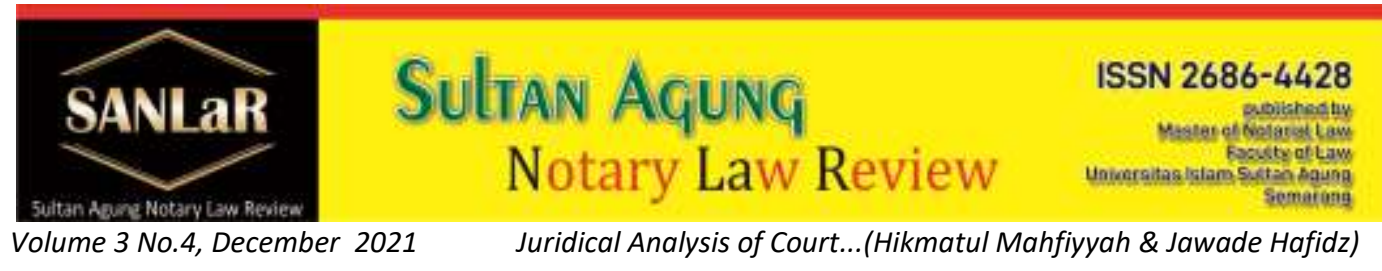

\title{
Juridical Analysis of Court Decisions Regarding Adopted Children in Their Position as Sole Heirs
}

\author{
Hikmatul Mahfiyyah*) and Jawade Hafidz**) \\ *) Faculty of Law, Universitas Islam Sultan Agung (UNISSULA) Semarang, E-mail: \\ hikmatulmahfiyyah026@gmail.com
}

$\left.{ }^{* *}\right)$ Faculty of Law, Universitas Islam Sultan Agung (UNISSULA) Semarang, E-mail: hafidzjawade@gmail.com

\begin{abstract}
It is human nature to live peacefully and happily with a complete family. As a complement to a family is the birth of children. When the offspring in the form of the desired child is not obtained naturally, it is done by adopting a child. The legal basis for regulating child adoption prior to the enactment of Government Regulation Number 54 of 2007 concerning the Implementation of Child Adoption, is carried out based on customary law, sharia law, and also based on a deed of adoption made before a notary, but after the enactment of Government Regulation Number 54 of 2007 concerning Implementation of Adoption child, the adoption of a child must be carried out through a court decision or stipulation. The need for a notary deed here is meant by the existence of a deed made before a notary, the deviations in a child adoption process will be minimized. The act of adopting a child contains juridical consequences that the adopted child has legal standing against the adopter, also includes the right to be able to inherit the wealth left by his adoptive parents at the time of death.
\end{abstract}

Keywords: Adoption; Child; Deed; Inheritance; Notary; Right.

\section{Introduction}

Adoption is one of the protections for adopted children. Child protection is all activities to guarantee and protect children and their rights so that they can live, grow and develop, and participate optimally in accordance with human dignity and protection from violence and discrimination. As for the facts that occur in the field that the adoption of children is generally carried out in a traditional manner without going through the local court. Faced with this dilemma, that does not always mean that the regulated actions are prohibited or allowed, but must be viewed on a case-by-case basis. ${ }^{1}$

The legal basis for regulating child adoption prior to the enactment of Government Regulation Number 54 of 2007 concerning the Implementation of

\footnotetext{
${ }^{1}$ Sudikno Mertokusumo, (1998), Mengenal Hukum (Suatu Pengantar), Yogyakarta: Liberty, p. 64
} 
Child Adoption, is carried out based on customary law, sharia law, and also based on a deed of adoption made before a notary, but after the enactment of Government Regulation Number 54 of 2007 concerning Implementation of Adoption child, the adoption of a child must be carried out through a court decision or stipulation. After the Government Regulation Number 54 of 2007 concerning the Implementation of Child Adoption was enacted, there were also efforts to reveal the role of the notary in the adoption process, although the role of the notary was not clearly stated but it was possible in the case that the notary made a deed of adoption which still had to go through court ratification ${ }^{2}$.

The act of adopting a child contains juridical consequences that the adopted child has legal standing against the adopter, also includes the right to inherit the wealth left by his adoptive parents at the time of death, but in reality a legal adopted child is still considered not part of the family which is the smallest community unit consisting of father, mother, and children, so that they are considered not entitled to the inheritance of their parents because they are not heirs of the parents who adopted them. This is because the influence of the Islamic legal system does not regulate the adoption of children who are used as biological children, this is not justified. For areas that recognize the existence of adopted children. ${ }^{3}$

\section{Research Methods}

The type of research used in the preparation of this thesis is normative juridical, meaning that the issues raised, discussed and described in this research are focused on applying the rules or norms in positive law. This type of normative juridical research is carried out by examining various kinds of formal rules such as laws, literatures that are theoretical concepts which are then linked to the problems that are the subject of discussion.

\section{Results and Discussion}

\subsection{Analysis of Legal Certainty of Notary Deed regarding Adoption of Adopted Children based on Laws Applicable in Indonesia}

\section{a. Position Case}

In this case, the author makes observations on the decision of the Jombang District Court Number 415/Pdt.P/2019/PN.Jbg, where based on the court's decision that the applicant on behalf of Kasman $\mathrm{H}$. was appointed by a married couple named Mr. Ngatemo alias Ngadi and Mrs. Jatemi as described in the Notary Deed Number dated 27 July 1967 drawn up by the Deputy Notary

\footnotetext{
${ }^{2}$ Ong Argo Victoria, Ade Riusma Ariyana, Devina Arifani. (2020). Code of Ethics and Position of Notary in Indonesia. Sultan Agung Notary Law Review 2 (4), 397-407, http://lppmunissula.com/jurnal.unissula.ac.id/index.php/SANLaR/article/view/13536

${ }^{3}$ Oemarsalim, (2000), Dasar-Dasar Hukum Waris di Indonesia, Jakarta: Rineka cipta, p. 28
} 
Soembono Tjiptowidjojo in Mojokerto. In the deed that during his life Ngadi Ngatemo was also written as Ngatemo alias Ngadi and his wife Ngatemi was also written as Jatemi was a respected person/capable, thus adopting a child named Kasman whose deed was made before Soembodo Tjiptowidjojo Deputy Notary in Mojokerto dated 27 July 1967.

In addition, that during his life Ngadi Ngatemo was also written as Ngatemo alias Ngadi and his wife (Ngatemi) was also written as Jatemi really did not know that the adoption of the child should have been to the District Court not to a notary. That the applicant intends to apply for the ratification of the notarial deed, among other things to manage inheritance and other legal needs, so that the applicant requires a determination from the Jombang District Court to be used as a legal basis.

\section{b. Legal Purpose Theory}

In realizing the legal objectives, Gustav Radbruch stated that it is necessary to use the priority principle of the three basic values which are the objectives of the law. Among the three basic values of the purpose of the law, in the event of a conflict, someone must be sacrificed. For this reason, the principle of priority used by Gustav Radbruch must be implemented in the following order: Legal Justice, Legal Benefits, Legal Certainty. ${ }^{4}$

Adoption is one of the protections for adopted children. Child protection is all activities to guarantee and protect children and their rights so that they can live, grow and develop, and participate optimally in accordance with human dignity and protection from violence and discrimination. As for the facts that occur in the field that the adoption of children is generally carried out in a traditional manner without going through the local court. Faced with this dilemma, that does not always mean that the regulated actions are prohibited or allowed, but must be viewed on a case-by-case basis. ${ }^{5}$

The value of legal certainty provides an explanation in terms of taking legal actions when adopting a child. child adoption arrangements prior to the enactment of Government Regulation Number 54 of 2007 concerning the Implementation of Child Adoption, are carried out based on customary law, sharia law, and also based on a child adoption deed made before a notary, but after the enactment of Government Regulation Number 54 of 2007 concerning the Implementation of Child Adoption, the adoption of a child must be carried out through a court decision or stipulation. ${ }^{6}$

\footnotetext{
${ }^{4}$ Muhammad Erwin, (2012), Filsafat Hukum, Jakarta: Raja Grafindo, p. 123

${ }^{5}$ Sudikno Mertokusumo. Op.cit pp. 64

${ }^{6}$ Article 1 Number 2 Government Regulation Number 54 of 2007 concerning the Implementation of Child Adoption
} 


\subsection{Analysis of Legal Certainty of Notary Deed regarding Adoption of Adopted Children based on Laws Applicable in Indonesia}

To implement the provisions regarding child adoption, the government issued Government Regulation Number 54 of 2007 concerning the Implementation of Child Adoption. Adoption is "a legal act that diverts a child from the sphere of authority of the parents, legal guardian, or other person responsible for the care, education and rearing of the child into the family environment of the adopted child."

Dodik Setyo Wijayanto SH, Jombang District Court Judge said that the adoption of children in general:

a. The first one talks about the facts on the ground about child adoption.

b. The second one talks about the existing laws and regulations regarding child adoption, there are two different aspects because there are indeed several forms of adoption:

1) First, we will look in general terms, when we talk about the provisions of laws and regulations, they are only regulated in the past, there are no specific rules in court, then starting from 1979, 1982 or 1985 there are, and then finally, the important point is there. PP Number 54 of 2007 concerning child adoption. Then PP 54 of 2007 has another derivative regulation, namely the Minister of Social Affairs Regulation number 110 of 2009 which regulates child adoption. 23 of 2002 concerning the protection of children, it is certain that it also regulates the adoption of children, but at a glance it is about the purpose of adopting other children.

2) then if you look at the type, there are several types, from the subject it can also from the procedure, judging from the subject, there used to be adoptions by Indonesian citizens and there were also adoptions by foreigners. but the verdict. Meanwhile, what is done by Indonesian citizens is the product of the court in the form of a determination. In terms of form, it could be the adoption of a child by a single parent... apart from that, there is the name adoption of a child according to customary law, there are times when that person adopts but he doesn't go to court, he has adopted a child, has been raised and so on. many people, ${ }^{7}$

In the event that the provisions for adopting a child through a notary are the method of adoption as regulated in the 1917 Staatblad Number 129 concerning child adoption, in which the regulation is only intended for the Chinese group and the only son who becomes a prospective adopted child is a boy. It is

\footnotetext{
7 Results of an interview with Dodik Setyo Wijayanto SH, Jombang District Court Judge, Conducted on October 8, 2021 at 14:30 WIB
} 
explicitly stated in the Staatblad that the adoption of a child must be by a notarial deed in which the interested parties must appear themselves or be represented by a special power of attorney who is authorized to do so.

Notaries as public officials can provide guarantees and legal protection through the formulation of authentic deeds that they make. A deed is a reflection of the fulfillment and implementation of rights and obligations between a legal subject and another legal subject. $R$ Subekti stated that in a civil case the main evidence is writing, while in a criminal case, testimony. ${ }^{8}$

Meanwhile, according to Nur Hidayat S, H., M.Kn Notary in Nganjuk, basically it is the duty of a notary to make a deed or to make a constitution but if there is no clear legal umbrella, then do not make it. The first is because the legal basis must exist and be clear, so the task of a notary regarding adoption has no legal basis, if it is permissible to make or declare a deed, if it is permissible to make a confession and/or statement of an adopted child, it is permissible for the parents to adopt it themselves. because the act was experienced personally, it was finally constated before a notary, it was allowed but if the notarized child adoption deed was made, it was not available. As for the legal certainty of the adoption deed made at a notary, Notary Nur Hidayat stated that for legal certainty there is no legal certainty, ${ }^{9}$

Regarding the deeds made by a notary before the enactment of the government regulation of the Republic of Indonesia Number 54 of 2007 concerning the Implementation of Adoption, it remains valid and still has binding legal force for the parties who agree to make them before a notary. This is as stated in the transitional law which states that at the time of the enactment of the government regulation of the Republic of Indonesia Number 54 of 2007 concerning the Implementation of Child Adoption, all laws and regulations relating to the implementation of child adoption remain valid as long as they do not conflict with the government regulation of the Republic of Indonesia Number 54 of 20072007 concerning the Implementation of Child Adoption.

A Notary Deed is an official document issued by a notary according to the Civil Code article 1870 and HIR article 165 (Rbg 285) which has absolute and binding evidentiary power. The Notary Deed is perfect evidence so that it no longer needs to be proven by other evidence as long as the untruth cannot be proven. Based on Article 1866 of the Civil Code and HIR 165, a notarial deed is the main written evidence or letter of evidence so that this document is a trial evidence that has a very important position. ${ }^{10}$

\footnotetext{
${ }^{8}$ R. Subekti, (1985), Pokok-Pokok Hukum Perdata, Jakarta: PT. Intermasa, p. 19

${ }^{9}$ Results of an interview with Nur Hidayat SH., Mkn, Notary in Nganjuk Regency, Conducted on October 25, 2021 at 14:30 WIB

${ }^{10}$ https://id.wikipedia.org/wiki/Akta_Notaris accessed on September 24, 2021 at 14:14 WIB
} 
Efforts to show the role of a notary after the enactment of Government Regulation Article 26 Number 54 of 2007 concerning the Implementation of Child Adoption, among others implied the role of a notary in legal acts of child adoption, where it is possible for a notary to play a role in providing guidance on the implementation of child adoption through counseling, consultation with related parties. With the adoption of a child, this is done so that the community, especially the parties in the legal act of adopting a child, get information and understand the requirements, procedures and procedures for adopting a child, because in counseling and consulting on legal actions that the parties want to take, a notary must refer to the laws and regulations relating to such legal acts.

Regarding the Notary's Role in Making Child Adoption Deeds, according to Notary Yulis Mariati, SH said that actually the realm of adoption according to Article 1 of the PJN notary is the only authorized official except for those assigned to make letters by other agencies, for example birth certificates, death certificates and marriage certificates. We don't continue to make adoptions, so if we make them, we are in the capacity of public officials, the only ones with authority are actually other agencies such as courts, but if we dare to make it, it's an authentic deed, the validity of which can be accounted for.

Regarding legal certainty regarding notarial deeds, Dodik Setyo Wijayanto SH, Jombang District Court Judge argued that the notarial deed was still valid but private in nature only between the person who adopted the person who was appointed or with the parents of the biological parents rather than the child who was adopted but not legally binding on third parties. ${ }^{11}$

Basically, the adoption of a child must be with a court decision, this is based on the circular letter of the Supreme Court dated April 7, 1979 No. 2 of 1979 concerning the Adoption of Children, it is stated, among other things, that the ratification of the adoption of children of Indonesian citizens can only be done by a decision in the district court, and it is not justified if the adoption is carried out with a deed legalized by the district court. ${ }^{12}$

\subsection{Analysis of How Legitimate Inheritance to Adopted Children as Sole Heirs}

Inheritance law that applies in Indonesia is divided into three, namely the Western Inheritance Law contained in the Civil Code, Customary Law, and Islamic Law. The basic regulations of inheritance law use the three legal systems described previously, which cannot be separated from the history of the

11 Results of an interview with Dodik Setyo Wijayanto SH, Jombang District Court Judge, Conducted on October 8, 2021 at 14:30 WIB

${ }^{12}$ Teddy Prima Anggriawan, Hukum Pengangkatan Anak Melalui Akta Pengakuan Pengangkatan Anak Yang Dibuat Oleh Notaris, Jurnal Pranata Hukum, Vol. 3, No. 1, February 2021, url : https://ejournal.widyamataram.ac.id/index.php/pranata/article/view/272/180, accessed on 16 November 2021 at 14:35 WIB 
Indonesian legal system during the colonial era, where the Dutch colonial government at that time made the Indische Staatsregeling (IS) regulations. Indonesian family law is pure and has parts, including Customary Law, Codified Civil Law and Oriental Civil Law. Especially in customary law, there is a plurality of laws which are contained in customary law which has differences from one region to another. The fact that the diversity of customary inheritance laws in various regions and ethnic communities creates difficulties in combining national inheritance laws. Marriage must have an impact on inheritance rules. Apart from those contained in the legislation carried out in accordance with local customs and religious beliefs and rules adopted by those who value marriage. Differences that occur in the marriage procedure as well as differences in accordance with beliefs that create conditions in which the incorporation of inheritance law will be difficult. Customary law is related to inheritance which generally uses the principle that the transfer of property is handed over by someone who has died..$^{13}$

In Staatsblad Number 129 of 1917 which explains that an adopted child and biological children of adoptive parents have the same rights. Therefore, adopted children in the family have the same position as biological children or children born to adoptive parents. This can also have consequences for the equality of rights and obligations of the adopted child, including in the distribution of the inheritance of his adoptive parents if they have died. So the position of adopted children in obtaining inheritance has the same rights as biological children regarding a legitimate child is a child born as a result of a legal marriage. Therefore, the position of adopted children even though they are not biological children has the same position in the eyes of the law, especially in the distribution of inheritance.

However, according to Islamic law, adopted children cannot be recognized to be used as the basis and cause of inheritance, because the main principles that cause inheritance in Islamic law are four things, namely: kinship or lineage relations, marital relations, wala 'relationships (relationship between master and slave). , and the purpose of Islam (ijtahul Islam), namely baitul mal which accommodates the inheritance of people who do not leave any heirs. ${ }^{14}$ So the event of adoption according to Islamic inheritance law does not have a legal effect on the status of an adopted child, that is, the adopted child does not inherit the inheritance from his adoptive parents. This of course will cause problems in the future if there are no rules in terms of inheritance, so the solution according to the Compilation of Islamic Law $(\mathrm{KHI})$ is to give a "compulsory will" as much as $1 / 3$ (one-third) of the inheritance of the adoptive

\footnotetext{
${ }^{13}$ Onesimus Sahuleka, "The Child Adoption in the Inheritance System of the Sentani Indigenous Community", Journal of Law, Policy and Globalization, Vol.49, p.2, accessed on 9 November 2021 at $11: 15$ WIB

${ }^{14}$ Ahmad Azhar Basyir, (2001), Hukum Waris Islam, Revision Edition, Yogyakarta: UII Press, p. 19
} 
parents. This is regulated in Article 209 Paragraph 2 of the Compilation of Islamic Law which reads: "About an adopted child who does not receive a will, he is given a mandatory will as much as $1 / 3$ of the inheritance of his adoptive parents." 15

As for the position of adopted children according to customary law, there are several jurisprudence of the Supreme Court, regarding the status and legal position in terms of inheriting from both adoptive parents, namely according to the jurisprudence of the Supreme Court stating that adopted children have the right to inherit the assets of their adoptive parents who are not is the property inherited by the adoptive parents. The jurisprudence of the Supreme Court states that regarding the applicable law in Central Java, adopted children are allowed to inherit gonogini property from their adoptive parents. So, for heirlooms and heirlooms, adopted children do not have the right to inherit them. The jurisprudence of the Supreme Court is based on customary law in force in East Sumatra, adopted children do not have the right to inherit the inheritance of their adoptive parents. ${ }^{16}$

\section{Conclusion}

Basically, the adoption of a child must be with a court decision, this is based on the circular letter of the Supreme Court dated April 7, 1979 No. 2 of 1979 concerning Adoption of Children, it is stated, among other things, that the ratification of the adoption of children of Indonesian citizens can only be done by a decision in the district court, and it is not justified if the adoption is carried out with a deed legalized by the district court. Child adoption cases must go through a district court decision and the deed made before a notary related to the child's recognition is only binding on what the parties want privately regarding the legal relationship of each party to the adoption of a child and does not have absolute legal force related to the legal status the adoption of the child if it is not registered and gets a decision by the District Court. In Article 174 of the Compilation of Islamic Law concerning the grouping of the heirs of adopted children, it is not included in the category of heirs because adopted children are not related by blood, lineage or marital relations, However, adoptive parents can still give part of their assets by means of grants or mandatory wills which were written or spoken by their adoptive parents before they died, in Article 209 paragraph 2 of the Compilation of Islamic Law, the mandatory will of the adopted child is given as much as $1 / 3$ of the assets inheritance of his adoptive parents. Regarding the inheritance status of the adopted child to his adoptive parents, is the adopted child entitled to inherit the inheritance from his adoptive parents based on Staatsblad Number 129 of 1917, or is he only entitled to

\footnotetext{
${ }^{15}$ Presidential Instruction No. 1/1991 on the Compilation of Islamic Law.

${ }^{16}$ Ridwan Jamal, "Kewarisan Anak Angkat Dalam Hukum Islam, Hukum Perdata Dan Hukum Adat", Jurnal Al-Syir'ah, Vol. 4 No. 2, p.13.
} 
receive inheritance from his adoptive parents through the mandatory will as stipulated by the Compilation of Islamic Law (KHI).

\section{References}

Journal:

[1] Onesimus Sahuleka, "The Child Adoption in the Inheritance System of the Sentani Indigenous Community", Journal of Law, Policy and Globalization, Vol.49, p.2

[2] Ong Argo Victoria, Ade Riusma Ariyana, Devina Arifani. (2020). Code of Ethics and Position of Notary in Indonesia. Sultan Agung Notary Law

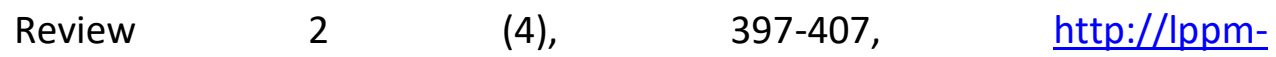
unissula.com/jurnal.unissula.ac.id/index.php/SANLaR/article/view/13536

[3] Ridwan Jamal, "Kewarisan Anak Angkat Dalam Hukum Islam, Hukum Perdata Dan Hukum Adat", Jurnal Al-Syir'ah, Vol. 4 No. 2, p.13.

[4] Teddy Prima Anggriawan, Hukum Pengangkatan Anak Melalui Akta Pengakuan Pengangkatan Anak Yang Dibuat Oleh Notaris, Jurnal Pranata Hukum, Vol. 3, No. 1, February 2021, url : https://ejournal.widyamataram.ac.id/index.php/pranata/article/view/27 $\underline{2 / 180}$

Books:

[1] Ahmad Azhar Basyir, (2001), Hukum Waris Islam, Revision Edition, Yogyakarta: UII Press

[2] Lili Rasjidin, (2001), Hukum Perkawinan dan perceraian di Malaysia dan di Indonesia, Bandung: PT.Remaja Rosdakarya

[3] Muhammad Erwin, (2012), Filsafat Hukum, Jakarta: Raja Grafindo

[4] Oemarsalim, (2000), Dasar-Dasar Hukum Waris di Indonesia, Jakarta: Rineka cipta

[5] R. Subekti, (1985), Pokok-Pokok Hukum Perdata, Jakarta: PT. Intermasa

[6] Sudikno Mertokusumo, (1998), Mengenal Hukum (Suatu Pengantar), Yogyakarta: Liberty

\section{Regulation:}

[1] Code of Civil law.

[2] Government Regulation Number 54 of 2007 concerning the Implementation of Child Adoption

[3] Act No. 2 of 2014 concerning Amendments to Law 30 of 2004 concerning Notary Positions

[4] Presidential Instruction No. 1/1991 on the Compilation of Islamic Law

[5] Supreme Court Circular No. 2 of 1979 concerning Adoption of Children

[6] Supreme Court Decision Number 210 K/Sip/1973

Internet:

https://id.wikipedia.org/wiki/Akta_Notaris accessed on September 24, 2021 